\title{
Prevalence of Shisha Smoking, with Risk (Physical) Factors among Private University Students in Erbil City
}

\section{Bayan Sabr Ebrahim (MSc) ${ }^{1}$}

\author{
${ }^{1}$ College of Dentistry, Hawler Medical University , Erbil ,Iraq \\ email: bayansabr@ymail.com
}

Received: 29 November 2020

Revised: 15 December 2020

Accepted: 10 January 2021

Published: 25 June 2021

Diyala Medical Journal 2021:20(2): 76- 81

\begin{abstract}
Background: Shisha involve charcoal, wood, or coal that conation tobacco to heat up. Tobacco inside the shisha called maassel, which often used. So shisha smoking is popular in every country especially among young people. As a result, shisha can be at risk of many clinical signs and symptoms like cough, chest pain, and symptoms of physical risk like hypertension, obesity, reduce body temperature.

Objective: To determine shisha smoking prevalence and associated physical factors among private university students in Erbil city.

Patients and Methods: Eight questionnaires about physical factors were administrated to 250 males and females among students in Erbil city in the present study.

Results: A total of two hundred and fifty individuals included in this study. Mean age of $(19.82 \pm 2.060)$ years. There are (164) shisha smokers among males and females private university students in Erbil city. Earlier plan questionnaire for (250) students was tested, (45.6\%) were male shisha smoking, and (20\%) were female in a cohort study. Compared to cigarette because characteristics in the way that shisha smoking is practiced the frequency of bloating and depth of inhalation smoking.

Conclusion: In the finding despite the scarcity of students indicate the high prevalence of obesity, reduce body temperature and increase blood pressure in shisha smokers. Can conclude in this study that shisha smoking has persistently been drop for, ten years period, increasingly people are turning to more healthy alternatives.
\end{abstract}

Keywords: Shisha; Temperature; Weight; Hydrostatic pressure; Color

\section{Introduction}

According to the centres for disease control and presentation (CDC). Smoking tobacco through shisha has many of the same health

risks as cigarettes. Smoking shisha in 16th country is a type of smoking tobacco invented. So, the device was to pass the 
smoke through water in an attempt to purify the smoke[1].

On average cigarette, for that reason, seem to absorb a lower toxic smoke than shisha smokers. At early stages, there is a broad evidence, of various harmful health effects after smoking shisha [2]. On average, shisha smokers seem to absorb a higher concentration of toxic smoke than cigarette smokers, because that shisha smoking is practiced such as the frequency of puffing and depth of inhalation compared to cigarette smoking[3].

At the showing pace tobacco smoking globally has been spread out [4].

Shisha smoking in the eastern Mediterranean region has been used, until recently, confined to adult, it is now gaining popularity among university students $[5,6]$.

Shisha smoking is also spread out to Western countries such as, Australia[7] , United Kingdom [8],Canada [9] and United States [10], where is also affecting students and teenagers $[11,12]$.

Also, due to the moist nature of shisha, the risk of contagious disease rises. $>100$ million people have been claimed wide world, smoke hookah daily [13]. Shisha was established in India and Persia centuries ago and it is a form of smoking tobacco that. Also, it is called waterpipe hookah, Hubble bubble smoking, narghile. At early stages there is emerging evidence, of various detrimental health effects after smoking shisha [14].

\section{Patients and Methods}

This study was carryied out on private university students in Erbil city. (Seven) questionnaires were administrated about physical factors to (250) males and females among students in Erbil city in the present
study.A total of (250) males and females included in this study. Physical factors (body temperature, weight, obesity, hydrostatic pressure, face color change, tooth color change, physical health) among private university students in Erbil city were determined. The body weight, body temperature diastolic and systolic blood pressure were determined in the outpatient setting and Nawruz Health centre after college duty for each individual.

\section{Statistical analysis}

Statistical analyses were performed using the Statistical Package for Social Science (SPSS) version (25).

\section{Results}

A total of two hundred and fifty participants were included in this study. Mean age was of $(19.82 \pm 2.060)$ years old. There are 164 shisha smokers among males and females private university students in Erbil city. In Table (1) Mean, standard. Deviation, standard error mean and mean difference has been measured for associated, physical factors and age for males and females, t-test for Equality of Means, $p$ value has been measured, $(\mathrm{p}>0.05)$.

Among (250) students' questionnaire was tested for each student validated, in a cohort study, 45,6\% were male shisha smoking, and $20 \%$ were female shisha smoking.In this study a total of (250) students included were with a minimum age of 18 and maximum age of $>18$ years old. So, the overall mean age was $(19.82 \pm 2.060)$ years old. The prevalence of males shisha smoking among participants was $45.6 \%$ and female was (20\%) in Erbil city. The obtained data (physical factor) about of shisha smoking are given in Table 
(2). Some individuals believe that shisha smoking does not lead to face colour changes, does not lead to reduce body weight, do not lead to fever. While shisha smoking-leads to an increase in blood pressure, obesity, reduction of body temperature, and discoloration of the teeth. The comparison between males and females was done in physical, associated factors and age. Shisha separated from an array of coal by foil, consists of a head that contains tobacco[2].

Table (1): Statistical analyses of distribution of the study participants who smoked shisha according to the sex and age

\begin{tabular}{|c|c|c|c|c|c|c|c|c|}
\hline & Gender & $\mathrm{N}$ & Mean & $\begin{array}{c}\text { Std. } \\
\text { Deviation }\end{array}$ & $\begin{array}{c}\text { Std. Error } \\
\text { Mean }\end{array}$ & $\mathrm{t}$-test & p-value & $\begin{array}{c}\text { Mean } \\
\text { Difference }\end{array}$ \\
\hline \multirow[t]{2}{*}{ Age } & Male & 211 & 19.82 & 2.060 & 0.142 & \multirow{2}{*}{0.891} & \multirow{2}{*}{ NS } & \multirow{2}{*}{0.051} \\
\hline & Female & 39 & 19.77 & 2.454 & 0.393 & & & \\
\hline \multirow{2}{*}{$\begin{array}{l}\text { Shisha smoking } \\
\text { get more cold } \\
\text { (get flu) }\end{array}$} & Male & 211 & 1.24 & 0.429 & 0.030 & \multirow{2}{*}{0.231} & \multirow{2}{*}{ NS } & \multirow{2}{*}{0.088} \\
\hline & Female & 39 & 1.15 & 0.366 & 0.059 & & & \\
\hline \multirow{2}{*}{$\begin{array}{l}\text { Shisha smoking } \\
\text { not reduce } \\
\text { weight }\end{array}$} & Male & 211 & $\begin{array}{c}1.03 \\
\end{array}$ & 0.180 & 0.012 & \multirow{2}{*}{0.807} & \multirow{2}{*}{ NS } & \multirow{2}{*}{0.008} \\
\hline & Female & 39 & 1.03 & 0.160 & 0.026 & & & \\
\hline \multirow{2}{*}{$\begin{array}{l}\text { Shisha smoking } \\
\text { rise blood } \\
\text { pressure }\end{array}$} & Male & 211 & 1.92 & 0.273 & 0.019 & \multirow{2}{*}{0.337} & \multirow{2}{*}{ NS } & \multirow{2}{*}{0.048} \\
\hline & Female & 39 & 1.87 & 0.339 & 0.054 & & & \\
\hline \multirow{2}{*}{$\begin{array}{l}\text { Shisha smoking } \\
\text { Decrease body } \\
\text { tempreture }\end{array}$} & Male & 211 & $\begin{array}{l}1.78 \\
\end{array}$ & 0.414 & 0.028 & \multirow{2}{*}{0.366} & \multirow{2}{*}{ NS } & \multirow{2}{*}{-0.064} \\
\hline & Female & 39 & 1.85 & 0.366 & 0.059 & & & \\
\hline \multirow{2}{*}{$\begin{array}{l}\text { Shisha smoking } \\
\text { lead to face } \\
\text { colour change }\end{array}$} & Male & 211 & 1.56 & 0.498 & 0.034 & \multirow{2}{*}{0.725} & \multirow{2}{*}{ NS } & \multirow{2}{*}{-0.031} \\
\hline & 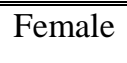 & 39 & 1.59 & 0.498 & 0.080 & & & \\
\hline \multirow{2}{*}{$\begin{array}{l}\text { Shisha smoking } \\
\text { lead to tooth } \\
\text { color change }\end{array}$} & Male & 211 & 1.33 & 0.472 & 0.032 & \multirow{2}{*}{0.356} & \multirow{2}{*}{ NS } & \multirow{2}{*}{0.075} \\
\hline & Female & 39 & 1.26 & 0.442 & 0.071 & & & \\
\hline
\end{tabular}


Table (2): Knowledge and physical factors with smoking shisha among participants(n=250)

\begin{tabular}{|c|c|c|c|}
\hline Issue & $\begin{array}{c}\text { Answer } \\
\text { (Yes/No) }\end{array}$ & $\mathrm{N}$ & $(\%)$ \\
\hline \multicolumn{4}{|c|}{ Shisha smoking leads to obesity } \\
\hline & & $\mathrm{N}$ & $(\%)$ \\
\hline & Yes & 206 & 82.40 \\
\hline & No & 44 & 17.60 \\
\hline \multicolumn{4}{|c|}{ Shisha smoking elevates blood pressure } \\
\hline & & $\mathrm{N}$ & $(\%)$ \\
\hline & Yes & 126 & 50.40 \\
\hline & No & 124 & 49.60 \\
\hline \multicolumn{4}{|c|}{ Shisha smoking not leads to fever } \\
\hline & & $\mathrm{N}$ & $(\%)$ \\
\hline & Yes & 32 & 12.80 \\
\hline & No & 218 & 87.20 \\
\hline \multicolumn{4}{|c|}{ Shisha smoking leads to face colour change } \\
\hline & & $\mathrm{N}$ & $(\%)$ \\
\hline & Yes & 145 & 58.00 \\
\hline & No & 105 & 42.0 \\
\hline \multicolumn{4}{|c|}{ Shisha smoking leads to teeooth discoloration } \\
\hline & & $\mathrm{N}$ & $(\%)$ \\
\hline & Yes & 205 & 82 \\
\hline & No & 45 & 18 \\
\hline \multicolumn{4}{|c|}{ Shisha smoking causes more colds } \\
\hline & & $\mathrm{N}$ & $(\%)$ \\
\hline & Yes & 195 & 78 \\
\hline & No & 55 & 22 \\
\hline
\end{tabular}

Shisha smoking causes more cold which means the smokers who complained from cold, they had a subnormal body temperature.

\section{Discussion}

In the Table (1), there are no significant differences between males and females in physical factor associated factors and age. Gender age are no significant differences associated with shisha smoking among participant, in the present study, $49.6 \%$ $(\mathrm{n}=124)$ were male shisha smoking, $16 \%(\mathrm{n}=$ 40) were female shisha smoking. The overall prevalence of shisha smoking among private university students in Erbil city is $65.6 \%$ ( $\mathrm{n}=$ $164)$, and non-shisha smoking is $34 \%(n=86)$.
In Tamin et al (2003), study the percentage of shisha smoking is high among college students that agreed with our students in which that the percentage of shisha smoking is also high among college students (\%65.60).

In the present study, body temperature was decreased in shisha smoking agreed with the study by Pelissier et al (1997) who reported, that body temperature was decreased during shisha smoking.

Also, in our study shisha smoking participants had a significantly higher blood pressure and this result agreed with according study by Amin Safi et al (2019). 
Shisha smoking is one of the causes of weight gain and that's clear that our results in the line with the another study done by Murtaza K. (2015), that shisha smoking associated with behaviours that lead to weight gain and significantly linked to obesity and increase the risk of users becoming obese.

The present study showed that shisha smoking exerts an effect on dental health and can stain the teeth with a pale yellowish discolorationstain from a physical outer surface, and this is agreed with result reported by Christine Frank (2019), who found that shisha smoking contains nicotine, over time is one reason of discoloured teeth and a change colour teeth.

Also, in Table (1), in a group of factors we note that the results is shown in minus symbol, which is means that in these factors the prevalence in females are more than males.

Also, smoking shisha a cause of face discoloration and damage to the skin which agreed finding result with the study done by Terry Martin (2020), that when someone mention the toll smoking take on your skin. Shisha smoking also get more cold than nonsmoking.

\section{Conclusions}

In the finding despite the scarcity of students indicate the high prevalence of obesity, decrees body temperature and increase blood pressure in shisha smokers. Can conclude in this study that shisha smoking has persistently been drop for, ten years period, increasingly people are turning to more healthy alternatives.

\section{Recommendations}

The author recommended the preventive implementation program to represents or highlights the effects of shisha smoking on systemic health and oral among students. It is also recommended that management of the social stain more effectively and the topic must be deriving in to the university.

\section{Source of funding: Nill}

Ethical clearance: No source of funding, no conflict of interest.

Conflict of interest: The author stated no opposition of interest.

\section{References}

[1]Maziak, W. The waterpipe: an emerging global risk for cancer. Cancer Epidemiol (2013); 37:1-4.

[2]Blachman-Braun, R. et al BuendíaRoldan Hookah, is it really harmless? Respir Med (2014); 108(5):661-7.

[3] Murtaza K. medical student, St. George's, A Abed Sweidan, A review of the health effects of smoking shisha. (2015); 15(3): 263 266.

[4] Maziak, W.et al. Tobacco smoking using waterpipe $\square$ a remerging strain in global epidemic, Tobacco control, (2004); vol.6(pg.457-63).

[5] Chaaya, M. et al. Argileh smoking among university students $\square$ a tobacco epidemic, Nicotine tobacco Rec. (2004); vol.6(pg.456630).

[6]Ai Turki YA. Smoking habits among medical students in central Saudi Arbia, Saudi Med J, (2006); vol.27(pg. 700-3).

[7]Carroll, T. Poder, N. and Perusco A. Is concern about waterpipe tobacco smoking warranted, Aust N Z Publ Health, (2008); vol. 32(pg.181-2). 
[8]Jakson, D. Aveyard, P. Waterpipe smoking in students $\square$ prevalence, risk factors symptoms of addiction, and smoke intake, Evidence from one british university. BMC Public Health, (2008); vol.8 pg.174.

[9]Reskin, J. Aveyard, P. Canada and English students' beliefs about waterpipe smoking $\square$ a qualitative study, BMC Public Health, (2009); vol. 9 pg.10

[10] Eissenberg, T. et al. Waterpipe tabacco smoking on a US college campus Prevalence and correlates, J Adolesc Health, (2008); vol. 42 (pg.526-9)

[11] Weglick, L. Comparison of cigarette and water pipe smoking by Arab and non-ArabAmerican youth, AM J Prev Med, 2008; vol. 35(pg. 334-9)

[12]Weglicki, L. Tobacco use patterns among high school students $\square$ do Arab American youth differ, Ethn Dis, (2007); vol. 17(2 Supple 3) (pg. S3-22-S3-4)

[13]Wolfram, RM. et al. Narghile(waterpipe) smoking influences platelet function and (iso) eicosanoids. Life Science, (2013); 74,47-53.

[14]Kirby, J. Health warning to shisha smokers. The Independent, 14 March 2012. Available online at www.independent.co.uk/life-style/healthand-families/health-news/health-warning-toshisha-smokers-7565842.html [Accessed 27]. (2015).

[15]Pelissier, AL. et al. Tobacco smoke influence on heart rate, body tempreture, and locomotor activity daily rhythms as assessed by radiotelemetry in rats. (1997); (pg.221-8). [16] Hala Tamin,Zana El Roueiheb, et al. Ci. garette and Waterpipe smoking among Lebanese Adolescentes, aCross-Section Study, 2003-2004. (2004);10(2):309-14.
[17] Ntina Alkhatib, Ruth D Holt and Raman Bedi. Smoking and tooth dislocation finding from a national cross section study.2005; 5(1):27.

[18]Terry Martin. Smoking Statistics from Around the World. 2020; 10389-008-0220-y. [19] Amin Safi, et al. Does shisha smoking affect blood pressure and heart rate.2009; 17(2):121-126. 